\title{
Effect of Chlordecone on the Reproductive Potential of the Cichlid Fish, Pseudetroplus Maculatus (Bloch, 1795)
}

\author{
Asifa KP, Chitra KC ${ }^{*}$ \\ Endocrinology and Toxicology Laboratory, Department of Zoology, University of Calicut, Kerala, India. \\ *Corresponding author: Chitra KC, Endocrinology and Toxicology Laboratory, Department of Zoology, \\ University of Calicut, Kerala, India. Email: kcchitra@yahoo.com
}

Received Date: 16 March, 2019; Accepted Date: 03 May, 2019; Published Date: 17 May, 2019

\section{Abstract}

The present study was undertaken to evaluate that chlordecone, an organochlorine pesticide, possessing estrogenic properties are known to influence the reproductive potential of the cichlid fish, Pseudetroplus maculatus. Chlordecone at two sublethal concentrations, 3.5 and $7 \mu \mathrm{g} / \mathrm{L}$, were exposed to fish for $4,7,15$ and 30 days in order to evaluate the level of vitellogenin, maintaining the control groups. Vitellogenin concentrations were measured in both male and female fishes by using indirect endpoints, such as alkali-labile phosphoprotein (ALP), total protein and calcium concentrations in the blood plasma. Increase in the concentrations of plasma protein, phosphoprotein, and calcium were time-dependant showing positive correlation when compared with the control groups. The remarkable raise in the level of vitellogenin in male fish indicated the estrogenic effects of chlordecone. However, gonadosomatic index was significantly decreased after the pesticide exposure, which could be due to gonadal-specific chlordecone toxicity. Sperm parameters such as sperm concentrations, viability and motility were evaluated at both sublethal concentrations for 24, 72 and $96 \mathrm{~h}$ maintaining the control groups. The significant decrease in the sperm parameters indicated that chlordecone affected normal functions of male gamete. The present results suggested that chlordecone influenced adverse effects on fish reproduction as evidenced by the elevated vitellogenin level in males with alteration in sperm functional parameters, which can be served as biomarker for the estrogenic effects of chlordecone in the cichlid fish.

\section{Keywords}

Alkali-labile phosphoprotein; Chlordecone; Gonadosomatic index; Plasma calcium; Sperm motility; Sperm viability

\section{Introduction}

During the past few decades, large number of environmental contaminants such as, pesticides, pharmaceutical drugs, plastic products, natural phytochemicals etc. has been continuously released into various compartments of both terrestrial and aquatic ecosystems, which are known to disrupt the endocrine system of animals, including humans. Such chemicals are called endocrine-disrupting chemicals (EDCs), which can interfere with biosynthesis, transport, action, metabolism and removal of various hormones in the body resulting in variation from normal homeostasis or reproduction [1]. Generally, EDCs are known to mimic or block the transcriptional activation of endogenous hormones by binding to its corresponding receptors. Other new mode of action for EDCs includes disruption of steroid hormone metabolism, proteasome-mediated degradation of receptor proteins, sensitization of hormones, and altered DNA methylation [2]. Persistence of several EDCs in various aquatic ecosystems have been associated to cause endocrine disruption and lead to several reproductive as well as developmental anomalies in fishes and other aquatic organisms $[3,4]$. Chlordecone is a synthetic chlorinated pesticide, commonly used for the control of various pests on tobacco, banana, citrus trees and ornamental shrubs. Structurally it is similar to mirex which is another insecticide widely used for the control of fire ants [5]. Chlordecone has been detected in those areas where mirex was applied as it is a photodegradation product of mirex [6]. Chlordecone is the more prominent persistent organic pollutant found in the environment, where it stick to suspended solids and sediments in water, and also has the ability to bioaccumulate in fish and other aquatic organisms thereby undergoes biomagnification through the food chain [7]. Chlordecone has been proven toxic to fish, in-terfering with antioxidant system of various tissues as gill, liver, brain [8] as well as muscle [9]. Acute exposure of chlordecone has been shown to 
induce the formation of micronucleus and other nuclear abnormalities such as blebbed, notched and lobed nuclei in the erythrocytes of Etroplus maculatus [10]. Chlordecone has been known to activate estrogen receptor- $\alpha$ and promote angiogenesis in human endothelial cells [11], and impaired male reproduction by the alteration in morphology of testes and arrest of sperm maturation in catfish [12].

Important biomarkers of endocrine disruption in fish includes measurement of vitellogenin (VTG) protein, plasma steroid hormones, histopathology of gonads, vitelline envelope proteins (VEPs), morphological features as facial tubercles and nuptial pads, male gender development, detection of enzymes involved in the biosynthesis of sex hormones like cytochrome P450 (CYP)-19, aromatase and C17-lyase and genes involved in estrogen response pathway [13]. Among these biomarkers, vitellogenin is considered as a potential biomarker of endocrine disruption by environmental estrogenic compounds in fish [14]. Vitellogenin is a Glyco-lipophosphoprotein that serves as a major precursor of egg yolk proteins, normally expressed in females and functions as an essential source of nutrients during early development of oviparous vertebrates and some invertebrates [15]. It is synthesized in liver in response to endogenous estrogens and transported to the ovary through the bloodstream, where it is taken up by oocytes and processed into yolk proteins [16]. In males, exogenous estrogenic compounds have been shown to mimic the endogenous estrogens and act on hepatic estrogen receptors which induce vitellogenin biosynthesis [17].

In order to detect the level of vitellogenin, several techniques have been developed globally, which includes enzyme-linked immunosorbent assay [18], non-competitive enzymatic immunoassays $[19,20]$, immune agglutination [21] and densitometry following electrophoresis $[22,23]$. Owing to the complexity of vitellogenin molecule and requirement of species-specific antibodies, these assays are limited to single species. In addition, these techniques are highly expensive and the use is restricted due to the lack of species-specific antibodies. Thus as an alternative to the techniques, indirect endpoints such as plasma protein, alkali labile phosphoprotein, plasma calcium and gonadosomatic index were frequently used to study the induction of vitellogenin in fishes [24]. Thus in the present study the estrogenic activity of chlordecone were measured using vitellogenin as biomarker by simple and reliable biochemical assays in the blood plasma of Pseudetroplus maculatus.

Pseudetroplus maculatus is a cichlid fish indigenous to South India and Sri Lanka, which inhabits both freshwater and brackish water habitats [25]. The biology of P. maculatus is well suited and thus widely used as laboratory model in toxicology studies as it is highly sensitive to the changing environmental conditions $[26,27]$. In fact, fishes are the top studied groups of aquatic animals mainly used to evaluate the developmental and reproductive toxicity due to the exposure of several environmental contaminants [28]. The present study was therefore designed to evaluate the estrogenic activity of chlordecone in vitellogenin and sperm parameters in the cichlid fish, Pseudetroplus maculatus.

\section{Materials and Methods}

\section{Animal}

Adult male and female freshwater cichlid fish, Pseudetroplus maculatus, $(7 \pm 1 \mathrm{~g}$ and $7 \pm 1.5 \mathrm{~cm})$ were collected from KKF Nursery, Manjeri, Vaniyambalam, Kerala, India. Fishes were brought to the laboratory with least disturbance and were acclimatized to the laboratory conditions for 15 days prior to experiments in dechlorinated and well-aerated aquarium tanks (40 L capacity). Health status of fish was continuously monitored throughout the experiment. The physico-chemical features of the tap water were estimated as prescribed in APHA guidelines [29] where water temperature $\left(28 \pm 2^{\circ} \mathrm{C}\right)$, oxygen saturation $(70$ to $100 \%)$ and $\mathrm{pH}(6.5$ to 7.5$)$ were maintained in the standard range throughout the treatment period.

\section{Chemicals}

Technical grade organochlorine pesticide, chlordecone (Kepone, decachlorooctahydro-1,3,4-metheno-2H-cyclobuta[cd]-pentalen-2-one, $99.9 \%$ purity) was obtained from Supelco, USA. Trichloroacetic acid, sodium hydroxide, methanol, acetone, hydrochloric acid, folin-ciocalteau reagent, lanthanum chloride, sucrose, eosin and nigrosin were obtained from Himedia Laboratories, Mumbai, India. All other chemicals were of analytical grade and obtained from local commercial sources.

\section{Treatment}

Chlordecone was dissolved in dimethyl sulfoxide (1\% DMSO), which was used as solvent control (vehicle) in the experiment. The median lethal concentration $\left(\mathrm{LC}_{50}-96 \mathrm{~h}\right)$ of chlordecone determined by probit analysis in the cichlid fish, Pseudetroplus maculatus was $35 \mu \mathrm{g} / \mathrm{L}$ [30]. After acclimatization, two sublethal concentrations $-3.5 \mu \mathrm{g} / \mathrm{L}$ and $7 \mu \mathrm{g} / \mathrm{L}(1 / 10$ th and $1 / 5$ th of $\mathrm{LC}_{50}$ ) of chlordecone were exposed to fish for $24 \mathrm{~h}, 72 \mathrm{~h}$ and 96 h ( 4 days), 7 days, 15 days and 30 days maintaining ten male and female fishes in each group.

\section{Experimental protocol}

At the end of every treatment period, fishes were caught very gently using a small dip net, one at a time with least disturbance and their body weights were noted. Blood and sperm samples were collected from control and treated groups and then the fishes were decapitated for dissecting gonads and weights were recorded. Estrogenic effect of chlordecone was evaluated by the following methods, which serve as a relevant biomarker to test the reproductive dysfunction in the fish.

\section{Gonadosomatic index (GSI)}

The relative gonad weight of treated and control fishes were calculated as follows: 
Citation: Asifa KP and Chitra KC (2019) Effect of Chlordecone on the Reproductive Potential of the Cichlid fish, Pseudetroplus maculatus (Bloch, 1795). J Aquat Res Mar Sci 2019: 163-177.

GSI $(\%)=($ Total gonad weight $(\mathrm{mg}) /$ total body weight $(\mathrm{mg})) \times 100$

\section{Collection of blood}

Blood samples were collected from both male and female fishes in separate clean micro centrifuge tubes using fine syringe by cardiac puncture method. Blood was centrifuged at $1700 \mathrm{~g}$ for $10 \mathrm{~min}$ at $4^{\circ} \mathrm{C}$ and plasma samples were collected and stored at $-80^{\circ} \mathrm{C}$ in micro centrifuge tubes for measuring vitellogenin concentration.

\section{Analysis of vitellogenin}

The plasma total protein concentration was determined according to Lowry et al. [31] using bovine serum albumin as standard. Alkali-labile phosphoprotein was measured using modified method of Wallace and Jared [32] and total plasma calcium levels were measured by atomic absorption spectrophotometry (Spectra-AA240FS, Varian) [33].

\section{Collection of sperm}

Sperm samples were collected from urino-genital tract by inserting catheter into culture container to prevent contamination. Collected sperm were transferred to a small petri dish and immediately used for testing sperm parameters:

\section{Sperm concentration}

Prior to determination of spermatozoa concentration, sperm was diluted 100 times with an immobilizing solution composed of Tris buffer (10 mM) and sucrose (100 mM; pH 8.5). A droplet $(10 \mathrm{ml})$ of diluted sperm suspension was placed on a counting chamber of the hemocytometer (depth $0.1 \mathrm{~mm}$ ) with a coverslip. The sperms are counted by using microscope at $40 \mathrm{X}$ magnification and sperm concentration was calculated according to method as described by Caille et al. [34]. Spermatozoa concentration is expressed as $10^{9}$ spermatozoa $/ \mathrm{ml}$.

\section{Sperm viability}

Sperm suspension $(20 \mu \mathrm{l})$ was mixed with an equal volume of $0.05 \%$ eosin-Y. After a minute of incubation at room temperature, slides were observed under microscope at 100X magnification for live and dead sperms and morphological abnormalities were also noted. Viable sperm remained colourless while non-viable sperm are stained in eosin and appeared pink [35]. Sperm were counted in control and treatment groups and viability was expressed in percentage [36].

\section{Sperm motility}

Sperm collected $(1 \mu \mathrm{l})$ was diluted with distilled water $(49 \mu \mathrm{l})$ and placed in on a Neubauer-type hemocytometer prepositioned on the microscope stage at $40 \mathrm{X}$ magnification. Sperm swimming activity was recorded for two minutes, and counted for motile and non-motile sperms. First non-motile sperm was counted followed by motile sperm and motility percentage was calculated, which was expressed as a percentage of motile sperm of the total sperm counted.

\section{Statistical analyses}

Statistical analyses were performed using a one-way analysis of variance (ANOVA) followed by Duncan's multiple range test using statistical package SPSS 19.0. Differences were considered to be significant at $\mathrm{p}<0.05$ against the control groups. Data are presented as mean \pm SD for ten animals per group. All biochemical estimations were carried out in duplicates.

\section{Results}

Fishes exposed to 1\% DMSO (solvent control) did not showed any remarkable variations in any parameters including gonadosomatic index, biochemical parameters or sperm parameters when compared with the negative control group. The gonadosomatic index was decreased significantly in duration and concentration-dependant manner in both male and female fishes after chlordecone exposure when compared to the control groups (Figure 1). Chlordecone exposure caused significant $(\mathrm{P}<0.05)$ increase in the levels of plasma protein, alkaline-labile phosphoprotein (ALP) and calcium in both males and females (Figures 2-4). Relationship between different plasma parameters were examined by linear-regression analysis and it showed positive correlation between plasma calcium and alkaline-labile phosphoprotein $(y=0.699 x-42.67 ; r=+0.9306)$, calcium and plasma protein $(\mathrm{y}=0.106 \mathrm{x}+3.891 ; \mathrm{r}=+0.9075)$, alkaline-labile phosphoprotein and plasma protein $(\mathrm{y}=0.143 \mathrm{x}+10.79$; $\mathrm{r}=+0.9181$ ) in male fishes (Figures 5-7). In female fishes, all plasma parameters were positively correlated showing correlation between plasma calcium and alkaline-labile phosphoprotein $(\mathrm{y}=0.892 \mathrm{x}+15.76 ; \mathrm{r}=+0.9437)$, calcium and plasma protein $(y=0.152 x-5.544 ; r=+0.9334)$, alkaline-labile phosphoprotein and plasma protein $(\mathrm{y}=0.152 \mathrm{x}-5.316 ; \mathrm{r}=+0.8833)$ (Figures $8-10)$. Chlordecone exposure showed significant $(\mathrm{P}<0.05)$ decrease in sperm concentration, motility and viability in duration and concentration-dependant manner when compared to the corresponding control groups (Figures 11-13). Sperm when stained with eosin showed colourless viable sperms in control groups and when the exposure period increased the dead sperms appeared pink colour along with morphological abnormalities such as enlarged sperm head and reduced or absence of sperm tail (Figure 14). 


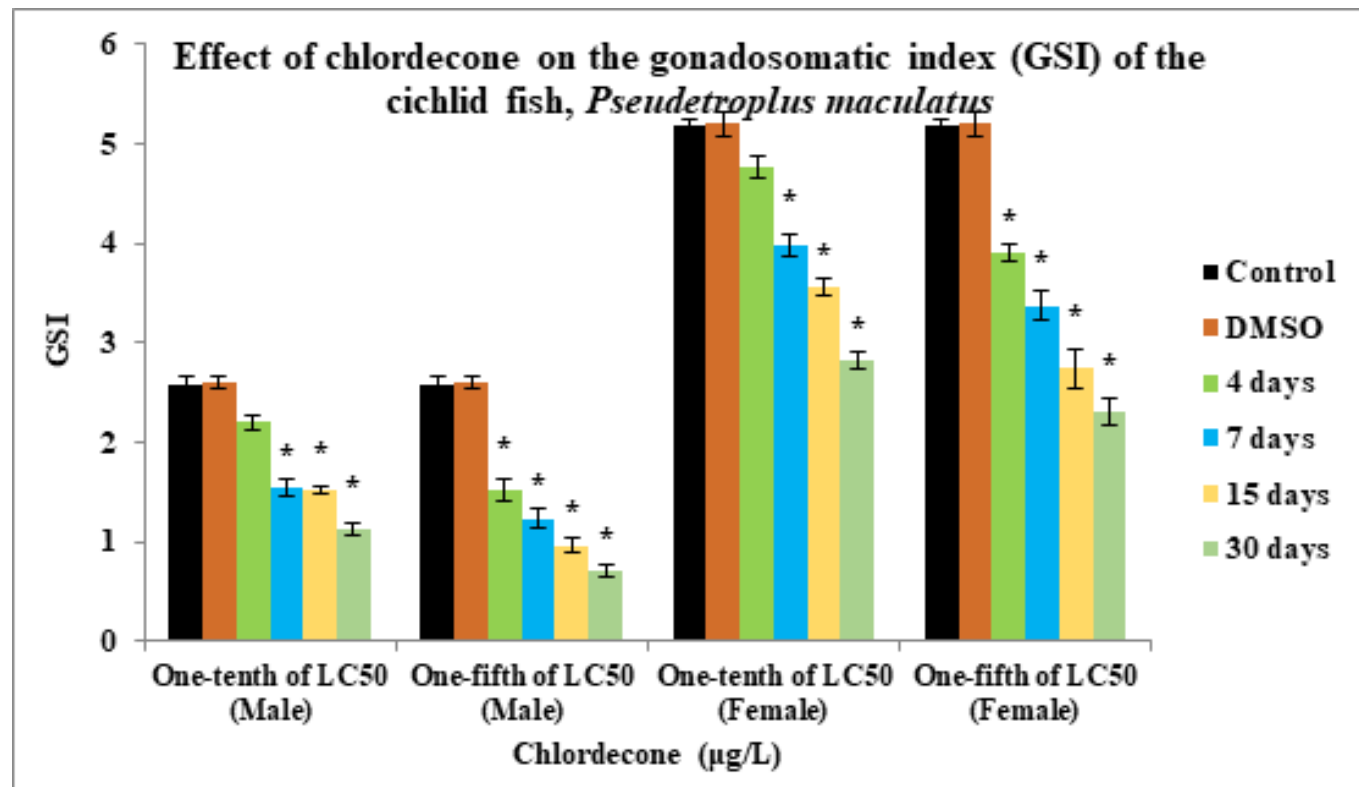

Figure-1

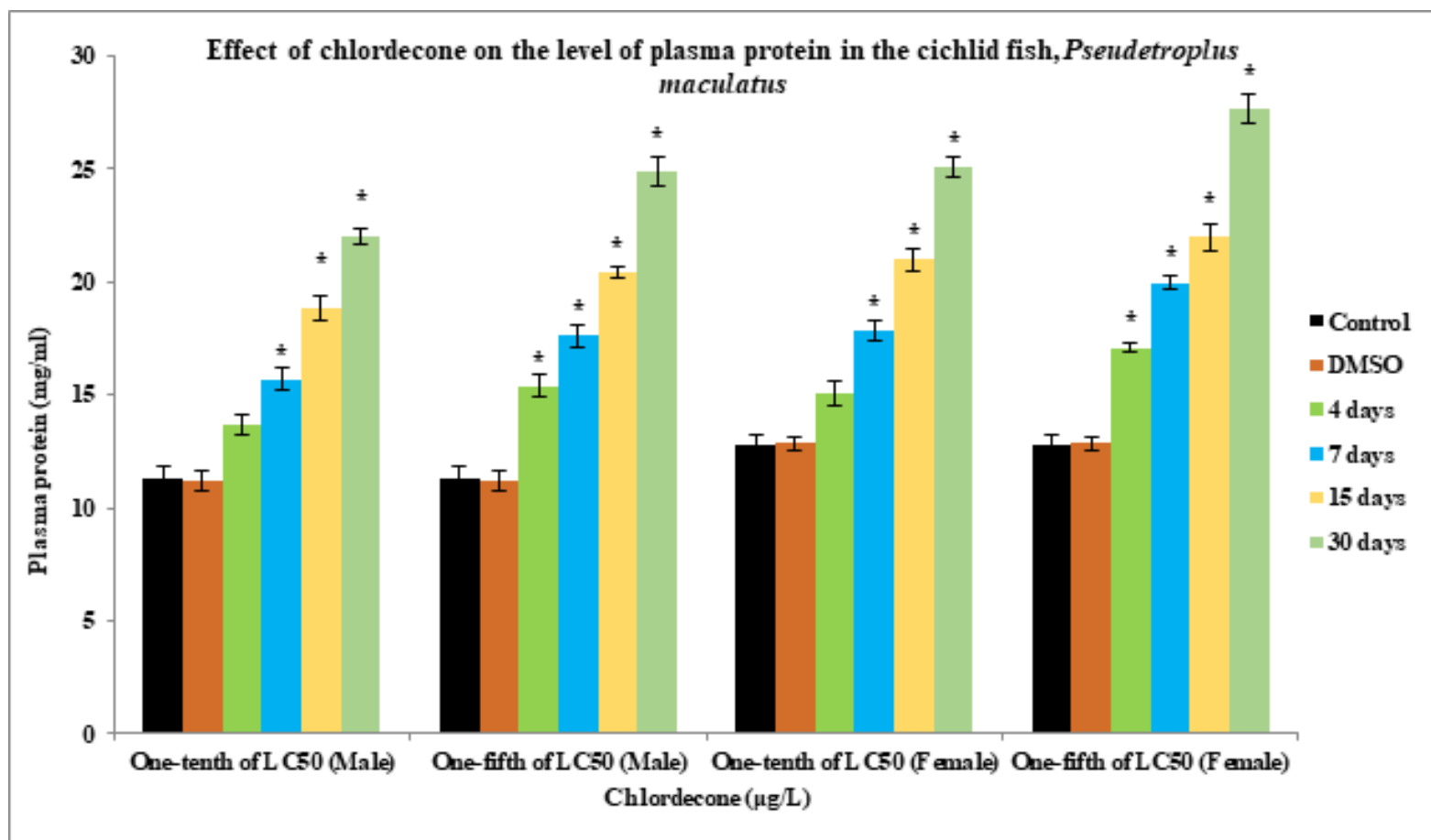

Figure-2 

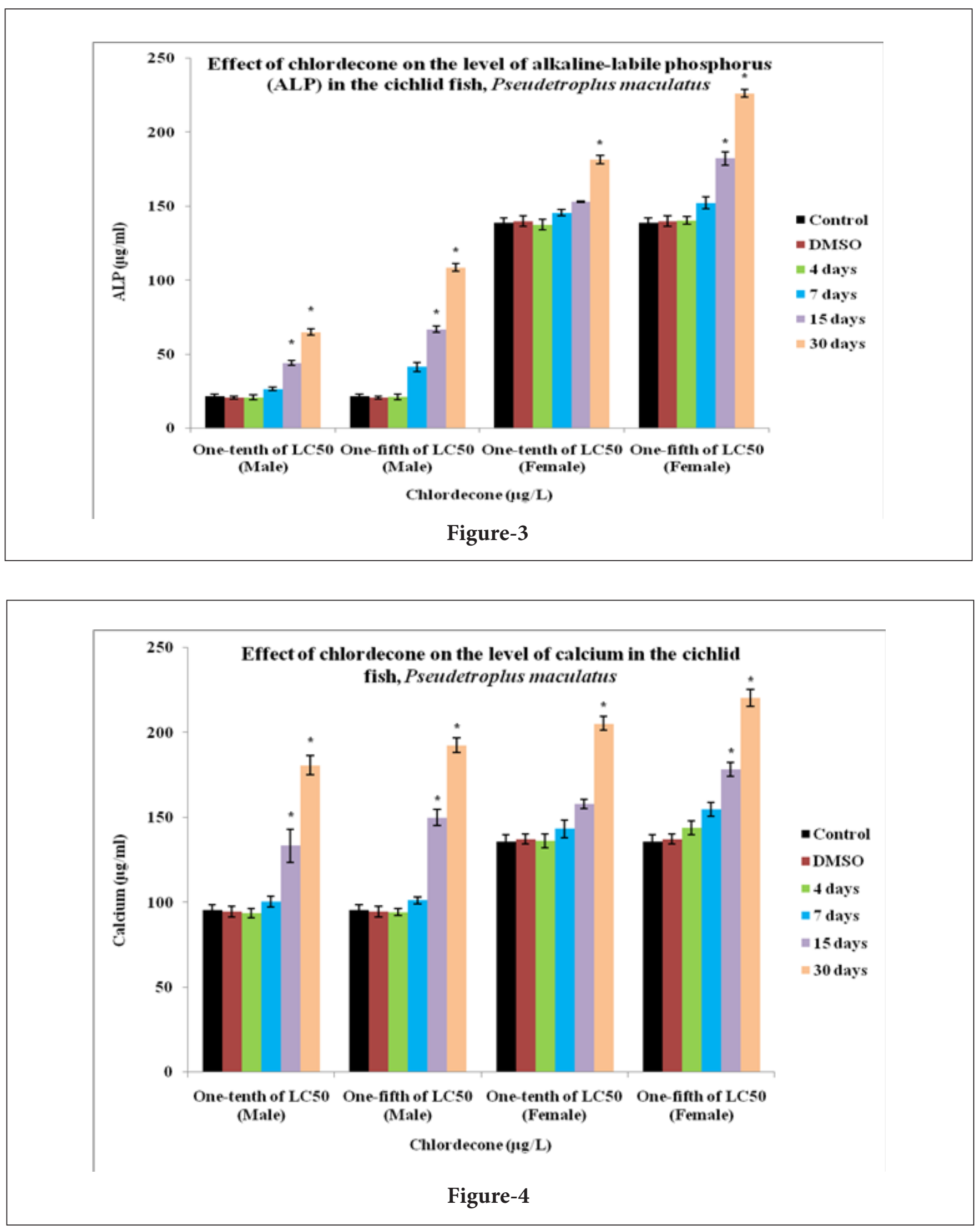


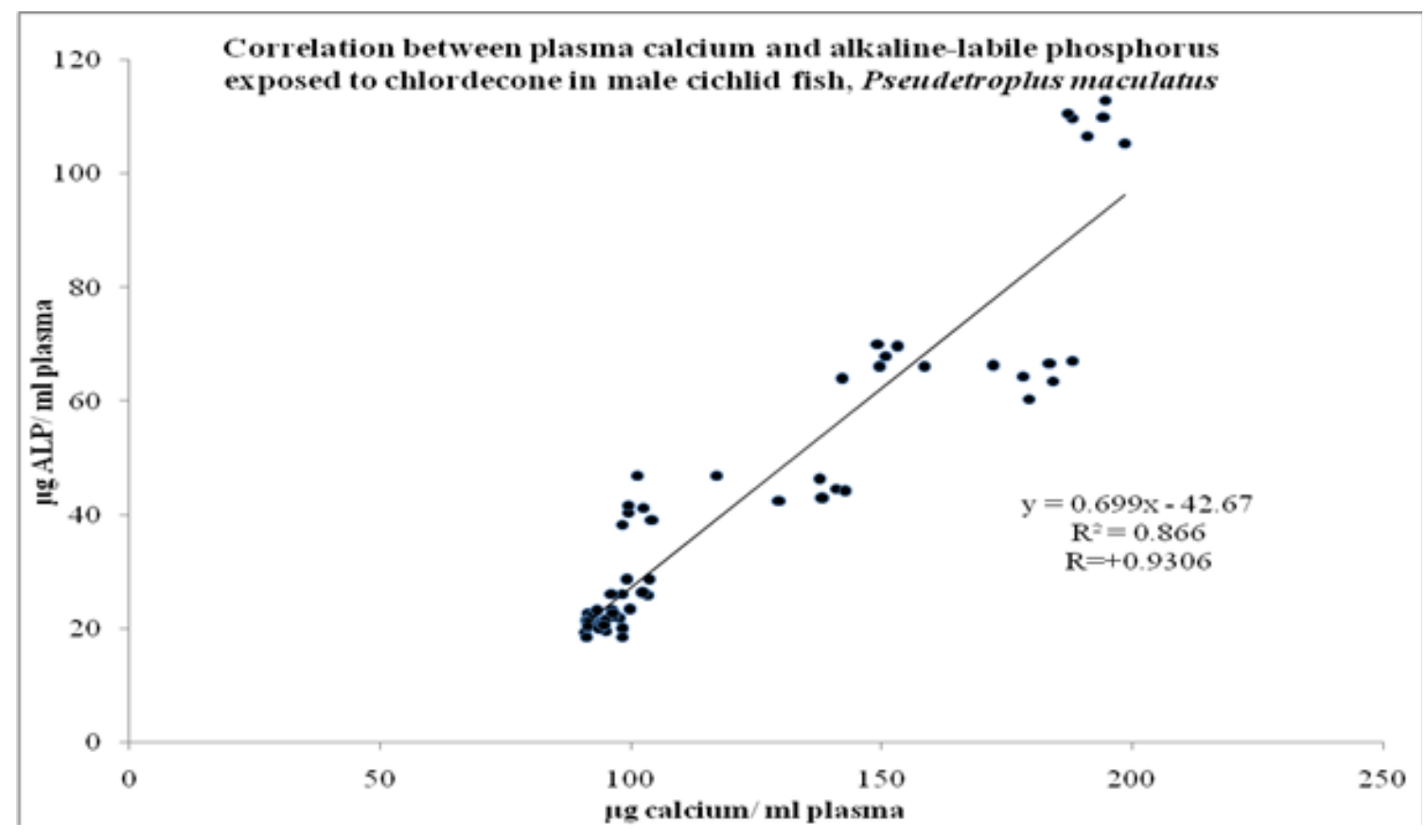

Figure-5

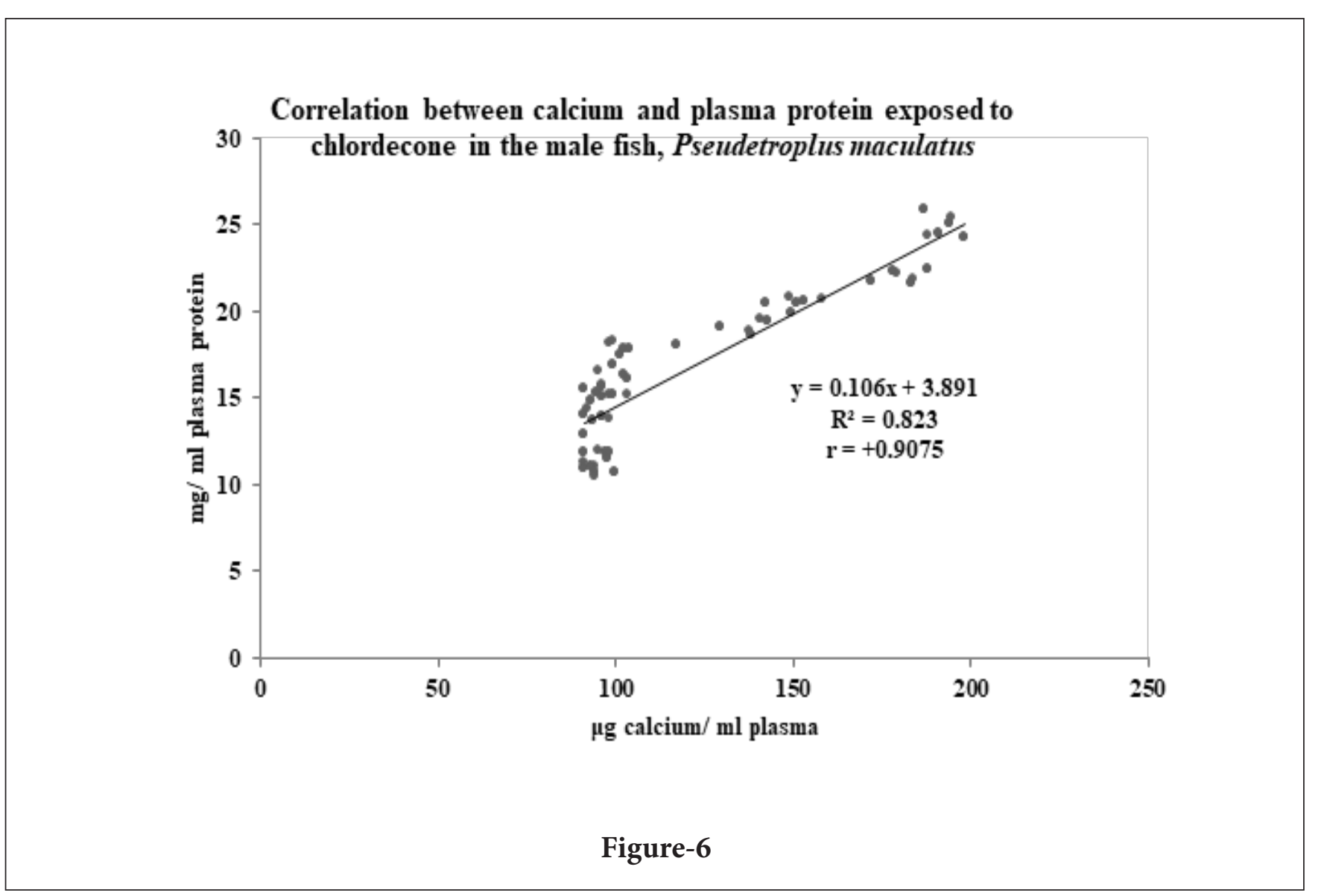



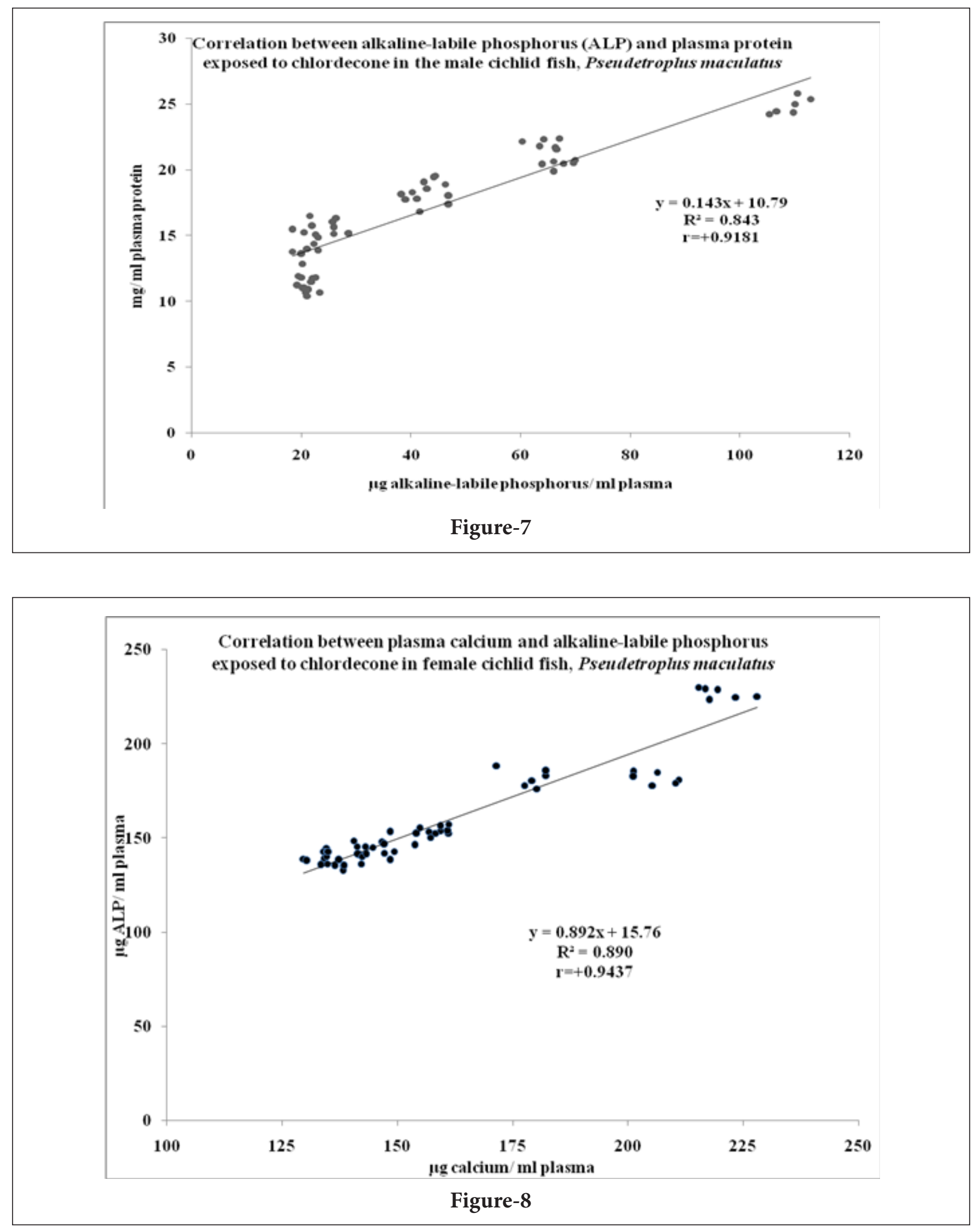

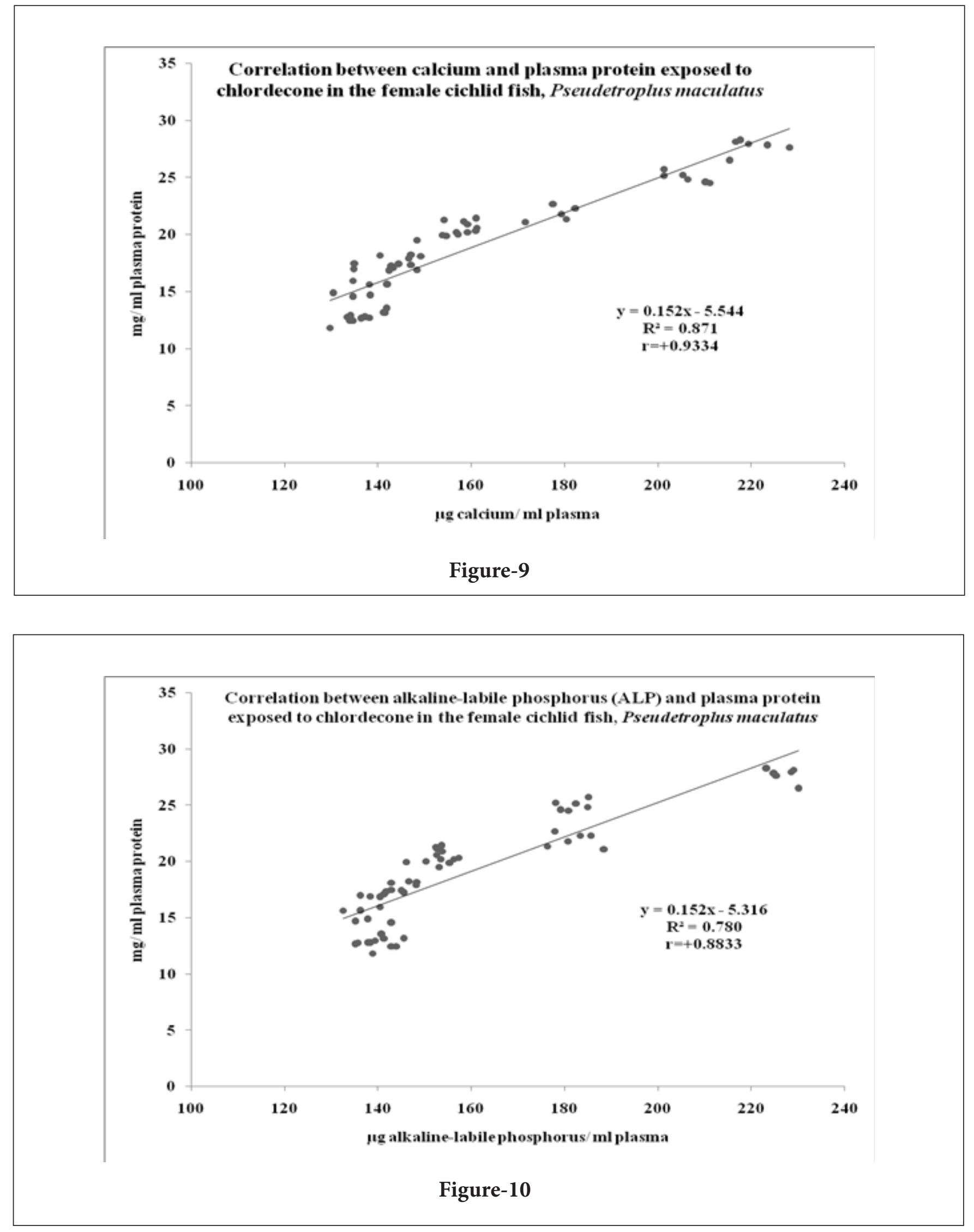

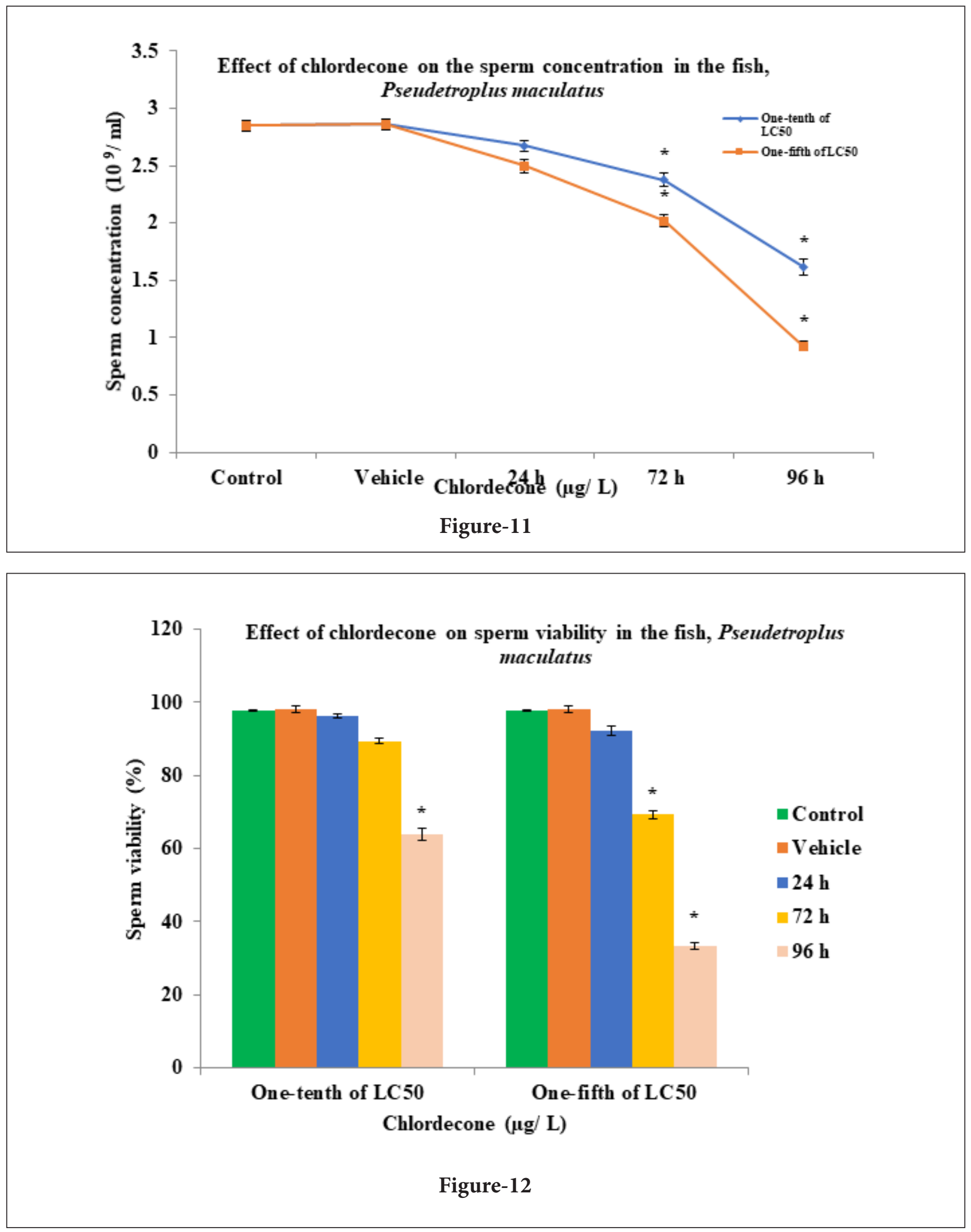


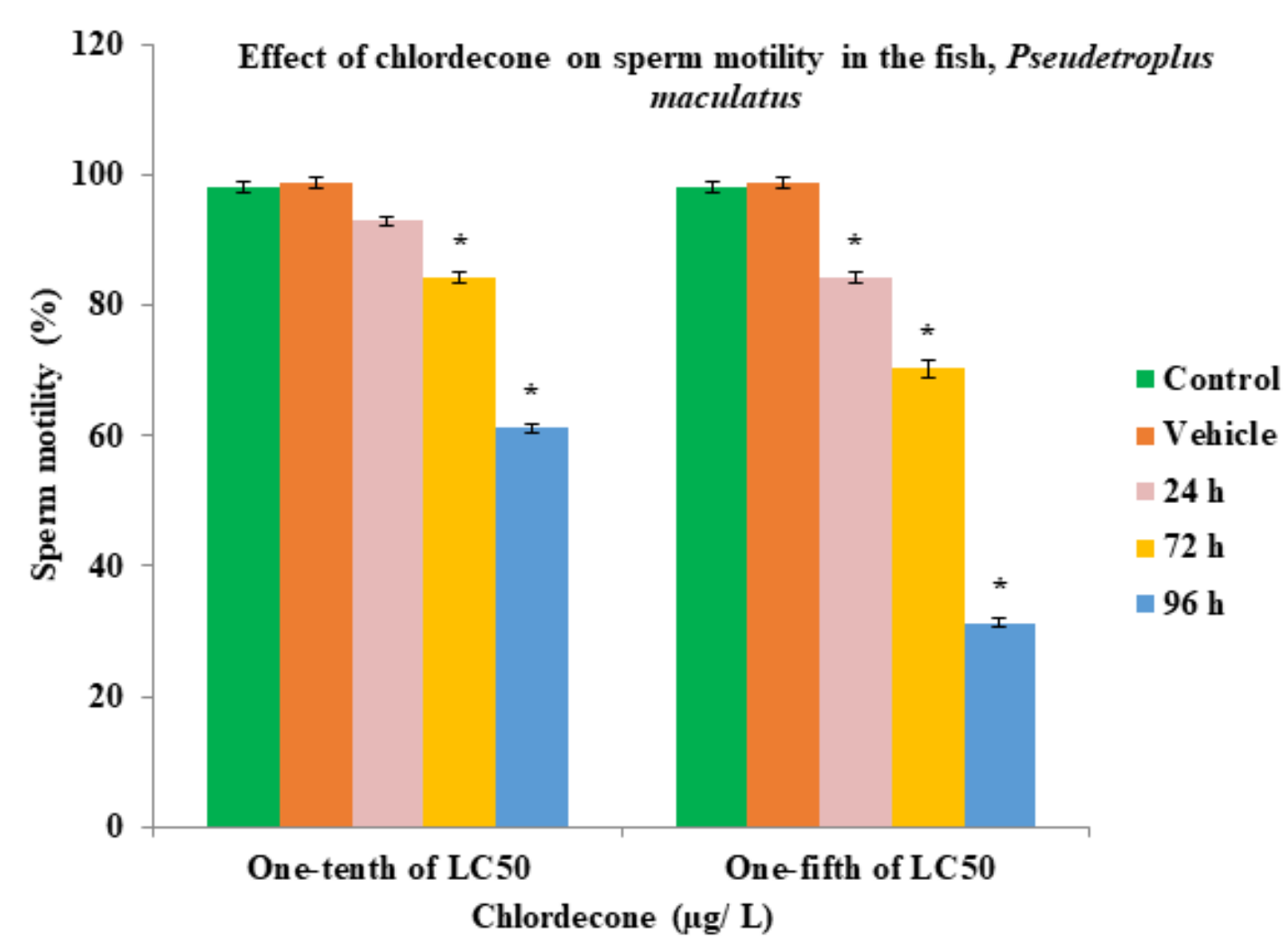

Figure-13

\section{Discussion}

In the early 1900s a specific antigen known as vitellogenin has been identified as the major precursor of egg yolk protein that is synthesized in female liver and is secreted into the blood and later incorporated into the egg [15]. Generally, the plasma content of vitellogenin has been shown to gradually increase along with oocyte development in female fishes [37] whereas the concentration found in males is scanty [38]. In males, the vitellogenin gene is normally silent, which can be induced after the treatment with estrogenic chemicals. Several environmental contaminants possessing estrogenic properties have been known to induce the production of female specific protein, vitellogenin, in male fishes $[39,40]$. Chlordecone, one of the environmental contaminants having estrogenic activity with high affinity for hepatic estrogen binding sites has been shown to induce vitellogenin production in rainbow trouts [41]. In the present study the induction of vitellogenin in males after the chlordecone exposure was determined using indirect endpoints such as the concentrations of plasma protein, alkali-labile phosphoprotein, calcium and gonadosomatic index and was compared with that of females. The impact of chlordecone on male reproduction was further analysed by measuring the sperm parameters as sperm concentration, motility and viability in the cichlid fish, Pseudetroplus maculatus.

During the reproductive cycles, the gonadosomatic index varies in male and females and is used as a relevant biological variable for assessing the reproductive health status of fish [42]. Hence it is the simplest and easiest measure to evaluate the gonadal dysfunction in fishes. Studies have revealed that exposure to various pollutants induced deteriorations in gonads involving reduction in gonadosomatic index along with morphological and histological variations in the gonads [43]. Chronic exposure to chlordecone decreased the relative weight of both testis and ovary of the fish in concentration and time-dependent manner. Similar result has been observed in the platyfish, Xiphophorus maculatus when exposed to nonylphenol and $17 \beta$-estradiol [44], and in Nile tilapia after nonylphenol exposure [45]. Reduction in the relative gonadal weight after chlordecone exposure might be due to gonad-specific toxicity.

Plasma protein concentrations in male and female fish after chlordecone exposure were significantly higher when compared with the control groups in concentration and time-dependent manner. Similar results were observed in rainbow trout when exposed to $17 \alpha$-ethinylestradiol [24]. Plasma protein concentration is considered as less sensitive endpoints in vitellogenin analysis. Therefore, alkali-labile phosphoprotein (ALP) or plasma calcium concentrations are used as indirect endpoints to determine plasma vitellogenin levels [46]. Vitellogenin is the only phosphorus containing protein in the blood of oviparous vertebrates having $0.6-0.8 \%$ protein-bound phosphorus [47]. After chlordecone exposure the plasma ALP and calcium 


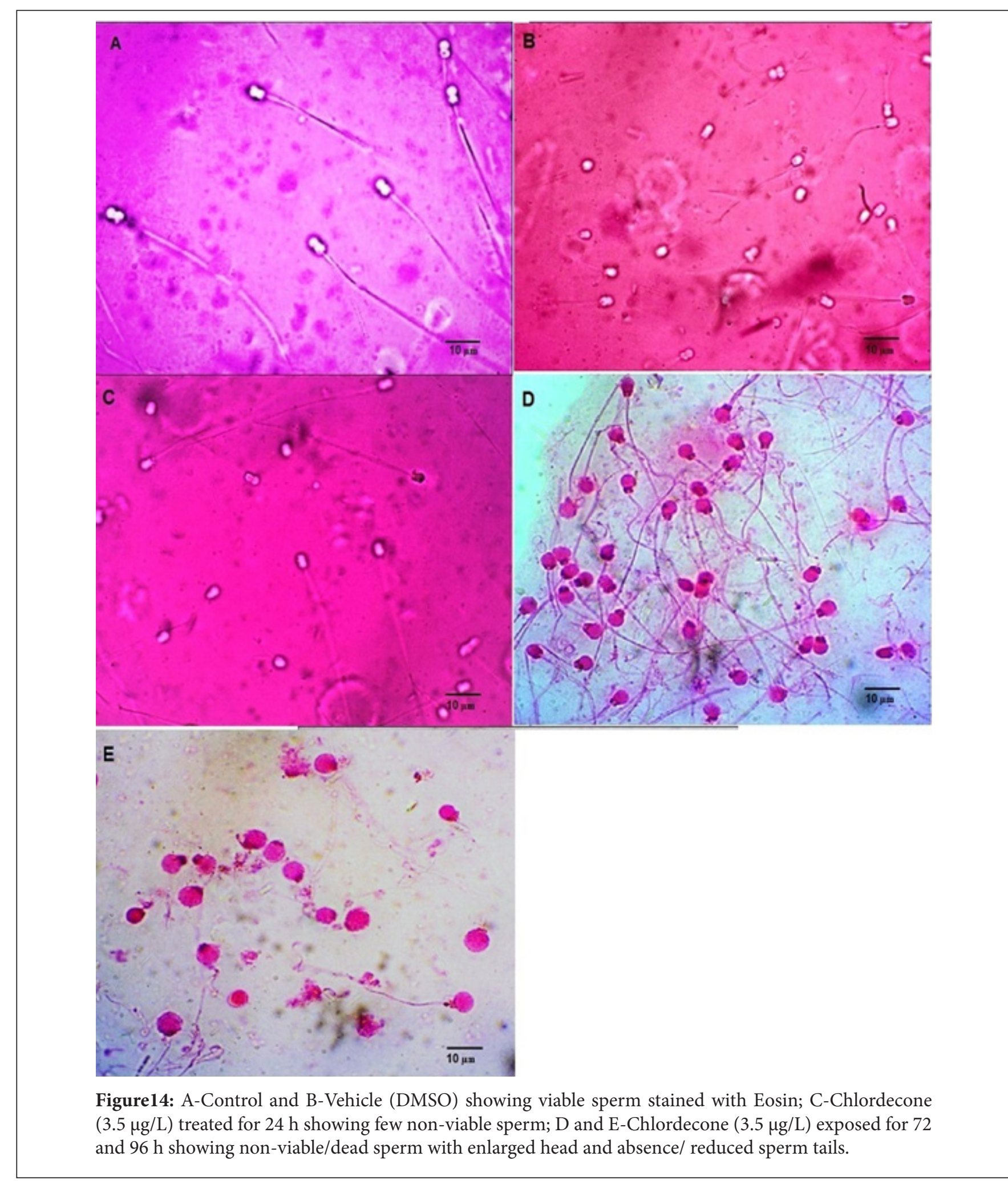

concentration increased to 2 -fold and 3 -fold levels in males when compared to the corresponding control groups and the increase was duration-dependent. In females, the plasma ALP and calcium levels increased only after 30 days of chlordecone exposure at $3.5 \mu \mathrm{g} / \mathrm{L}$ concentration and after 15 and 30 days of exposure at higher concentration $(7 \mu \mathrm{g} / \mathrm{L})$ when compared with the controls. The results of this study confirmed that male fish lack the ability to remove vitellogenin from their blood, unlike its uptake into oocytes in case of females. Therefore, vitellogenin concentrations remained high in the plasma of males for several weeks after chlordecone exposure. The significant induction in all measured plasma parameters indicates the est- 
rogenic response of chlordecone in the exposed fish. Induction in plasma ALP and calcium concentration has been reported in highly vitellogenic mature females and estradiol injected immature rainbow trouts [48]. Moreover, plasma protein, ALP and calcium levels were significantly and positively correlated in both male and female fish after chlordecone exposure. Thus elevated level of plasma vitellogenin in male fish can be used as an indicator of reproductive dysfunction. The embryos produced from such males in the environment exposed to toxicant may suffer reproductive effects such as gonadal feminization and reduced fertility as adult males [49]. Similarly the elevated levels of plasma vitellogenin in females are associated with decrease in estradiol production, which in turn affects the egg production [50].

The effects of chlordecone in male reproduction was further analysed by evaluating sperm functional parameters as sperm concentration, motility and viability. In most of the fish species with external fertilization, the spermatozoa remain quiescent in gonadal seminal plasma. It becomes motile and metabolically active only when released into the aqueous environment during natural reproduction or into diluents during artificial reproduction. Motility is initiated by several factors of external and internal environments which vary among different species of fishes. In euryhaline fish, medaka, sperm motility is inversely proportional to osmolality [51] whereas in Oreochromis mossambicus, divalent cations $\left(\mathrm{Ca}^{2+}\right)$ are required for the activation of sperm motility [52]. Thus in most of the teleost fishes, osmolality and $\mathrm{K}+$ are responsible for motility of sperm [53] whereas in Larimichthys polyactis sperm motility is highly sensitive to variations in $\mathrm{pH}$, temperature and cations [54]. Generally, in the case of freshwater species, motility could last less than two minutes following activation [55]. Thus in the present study, immediately after the collection of sperm the motility was observed for two minutes and it was found that chlordecone exposure significantly decreased the motility of sperm at both sublethal concentrations. Male fertility in fish highly depends on sperm motility and the present results indicate chlordecone exposure affects the male fertility.

Fish sperms have restricted ability to withstand the physicochemical changes in their external environment [56]. Therefore, it is highly susceptible to disturbances caused by the environmental contaminants that include impaired gonadal development, decreased steroidogenesis, testicular impairment, and oxidative stress-induced testicular toxicity $[57,58]$. Besides, exposure to environmental contaminants has been shown to interfere with the activation of sperm that result in demasculinization, reduced sperm motility, viability and count along with reduction in gametic viability, fertilization potential and embryonic development [59,60,61].

High level of chlordecone exposure among the employees in the production factory has been shown to cause significant reduction in sperm counts and oligospermia that leads to male infertility [62]. In rats, administration of chlordecone at 15-30 ppm for 60 days decreased sperm reserves in the cauda epididymidis, and motility and viability of epididymal spermatozoa without affecting sperm morphology and concentration in epididymal fluid [63]. The present result showed that chlordecone exposure significantly decreased the sperm concentration, sperm viability and sperm count in concentration and time-dependent manner when compared to the control groups. The motility and viability of sperm showed close correlation. Chlordecone exposure at one-tenth of $\mathrm{LC}_{50}$ concentration $(3.5 \mu \mathrm{g} / \mathrm{L})$ was used to evaluate sperm viability and it was observed that all viable sperms were motile and non-viable sperms were non-motile. In non-viable sperms at $96 \mathrm{~h}$ of chlordecone exposure, head is enlarged and the tail is shortened or entirely absent. The decrease in sperm motility and viability may be due to the induction of oxidative stress in gonads $[64,65]$. Decreased sperm functions may be also due to failure of endocrine system or degenerative changes in the gonad structure as a result of chlordecone toxicity.

To brief, the induction of vitellogenin in male fish using simple and reliable protocol was used as a biomarker to detect estrogenic effects of chlordecone. Corresponding increase of vitellogenin in female fish indicated decrease in egg production. Further, decline in sperm parameters designated chlordecone induced reproductive dysfunction in the cichlid fish, Pseudetroplus maculatus.

\section{Acknowledgement}

Authors gratefully acknowledge the financial grant from Kerala State Council for Science, Technology and Environment (KSCSTE), Thiruvananthapuram, Kerala to carry out this study.

\section{References}

1. Diamanti-Kandarakis E, Bourguignon JP, Giudice LC, Hauser R, Prins GS et al. (2009) Endocrine-disrupting chemicals: an endocrine society scientific statement. Endocr Rev 30: 293-342.

2. Tabb MM, Blumberg B (2006) New modes of action for endocrine-disrupting chemicals. Mol Endocrinol 20: 475-482.

3. Vos JG, Dybing E, Greim HA, Ladefoged O, Lambre C et al. (2000) Health effects of endocrine-disrupting chemicals on wildlife, with special reference to the European situation. Crit Rev Toxicol 30: 71133.

4. Ankley GT, Johnson RD (2004) Small fish models for identifying and assessing the effects of endocrine-disrupting chemicals. ILAR J 45: 469-483.

5. Agency for Toxic Substances and Disease Registry (ATSDR) Toxicological profile for mirex and chlordecone. Atlanta, GA: U.S. Department of Health and Human Services, Public Health Service 1995.

6. Carlson DA, Konyha KD, Wheeler WB, Marshall GP, Zaylskie RG (1976) Mirex in the environment: its degradation to kepone and related compounds. Science 194: 939-941.

7. Fisher DJ, Clark JR (1990) Bioaccumulation of kepone by grass shrimp (Palaemonetes pugio): importance of dietary accumulation and food ration. Aquatic Toxicol 17: 167-186.

8. Asifa KP, Chitra KC (2017) Evidence for chlordecone-stimulated ox- 
Citation: Asifa KP and Chitra KC (2019) Effect of Chlordecone on the Reproductive Potential of the Cichlid fish, Pseudetroplus maculatus (Bloch, 1795). J Aquat Res Mar Sci 2019: 163-177.

idative stress in different tissues of the cichlid fish, Pseudetroplus maculatus (Bloch, 1795). Croatian J Fisheries 5: 67-76.

9. Asifa KP, Vidya PV, Chitra KC (2016) Chlordecone-induced changes in muscular antioxidant system of cichlid fish, Etroplus maculatus (Bloch, 1795). Int J Res 3: 21-29.

10. Asifa KP, Vidya PV, Chitra KC (2016) Genotoxic effects of chlordecone in the cichlid fish, Etroplus maculatus (Bloch, 1795) using micronucleus test. Res J Recent Sci 5: 16-20.

11. Alibrahim EA, Andriansitohaina $R$, Hardonniere $K$, Soleti R, Faure $S$ et al. (2018) A redox-sensitive signaling pathway mediates pro-angiogenic effect of chlordecone via estrogen receptor activation. Int J Biochem Cell Biol; 97: 83-97.

12. Srivastava AK, Srivastava AK (1994) Effects of chlordecone on the gonads of freshwater catfish, Heteropneustes fossilis. Bull Environ Contam Toxicol; 53: 186-191.

13. Hutchinson TH, Ankley GT, Segner H, Tyler CR (2006) Screening and testing for endocrine disruption in fish-biomarkers as" signposts," not" traffic lights," in risk assessment. Environ Health Perspect 114: 106-114.

14. Hansen PD, Dizer H, Hock B, Marx A, Sherry J et al. (1998) Vitellogenin-a biomarker for endocrine disruptors. Trends in Analytical Chemistry 17: 448-451.

15. Wallace RA. Vitellogenesis and oocyte growth in non-mammalian vertebrates. In: Browder LW (Ed). Development Biology, Plenum Press, New York 1985 127-177.

16. Reading BJ, Sullivan CV. Vitellogenesis in fishes. In: Farrell AP, Stevens ED, Cech Jr JJ, Richards JG (Eds). Encyclopedia of Fish Physiology, Academic Press, Inc. Maryland Heights, 2011, 635-646.

17. Pelissero C, Flouriot G, Foucher JL, Bennetau B, Dunogues J et al. (1993) Vitellogenin synthesis in cultured hepatocytes; an in vitro test for the estrogenic potency of chemicals. J Steroid Biochem Mo Biol; 44: 263-272.

18. Nilsen BM, Berg K, Eidem JK, Kristiansen SI, Brion F et al. (2004) Development of quantitative vitellogenin-ELISAs for fish test species used in endocrine disruptor screening. Anal Bioanal Chem 378 621-633.

19. Bon E, Barbe U, Rodriguez JN, Cuisset B, Pelissero C et al. (1997) Plasma vitellogenin levels during the annual reproductive cycle of the female rainbow trout (Oncorhynchus mykiss): establishment and validation of an ELISA. Comp Biochem Physiol B Biochem Mol Biol 117: 75-84.

20. Brion F, Rogerieux F, Noury P, Migeon B, Flammarion P et al. (2000) Two-step purification method of vitellogenin from three teleost fish species: rainbow trout (Oncorhynchus mykiss), gudgeon (Gobio gobio) and chub (Leuciscus cephalus). J Chromatogr B Biomed Sci Appl 737: 3-12

21. LeBail PY, Breton B (1981) Rapid determination of the sex of puberal salmonid fish by a technique of immunoagglutination. Aquaculture 22: $367-375$

22. Van Bohemen CG, Lambert JGD, Peute J (1981) Annual changes in plasma and liver in relation to vitellogenesis in the female rainbow trout, Salmo gairdneri. Gen Compar Endocrinol 44: 94-107.

23. Allner B, Wegener G, Knacker T, Stahlschmidt Allner P (1999) Electrophoretic determination of estrogen-induced protein in fish exposed to synthetic and naturally occurring chemicals. Sci Total Environ 233: 21-30.
24. Verslycke T, Vandenbergh GF, Versonnen B, Arijs K, Janssenet CR (2002) Induction of vitellogenesis in 17a-ethinylestradiol-exposed rainbow trout (Oncorhynchus mykiss): a method comparison. Comp Biochem Physiol C Toxicol Pharmacol 132: 483-492.

25. Pethiyagoda R, Maduwage K, Manamendra Arachchi K (2014) Validation of the south Asian cichlid genus Pseudetroplus bleeker (Pisces: Cichlidae). Zootaxa 3838: 595-600.

26. Asifa KP, Chitra KC (2016) Effects of nonylphenol-induced oxidative stress in ovary of cichlid fish, Etroplus maculatus (Bloch, 1795). Int Letters Natural Sci 58: 11-15.

27. Das P, John G (1999) Induction of sister chromatid exchanges and chromosome aberrations in vivo in Etroplus suratensis (Bloch) following exposure to organophosphorus pesticides. Toxicol Lett 104: $111-116$

28. Kime DE (1995) The effects of pollution on reproduction in fish. Rev Fish Biol Fisheries 5: 52-95.

29. American Public Health Association, APHA. Standard methods for the examination of water and waste water, 20thed, Washington, DC. 1998.

30. Asifa KP, Chitra KC (2015) Determination of median lethal concentration (LC50) and behavioural changes on the cichlid fish, Etroplus maculatus exposed to chlordecone. Int J Sci Res 4: 1473-1475.

31. Lowry OH, Rosebrough NJ, Farr AL, Randall RJ (1951) Protein measurement with the Folin phenol reagent. J Biol Chem 193: 265275 .

32. Wallace R, Jared D (1968) Studies on amphibian yolk. VII. Serum phosphoprotein synthesis by vitellogenic females and estrogen-treated male Xenopus laevis. Can J Biochem 46: 953-959.

33. Zettner A, Seligson D (1964) Applications of atomic absorption spectroscopy in the determination of calcium in serum. Clinical Chemist 10: 869-890.

34. Caille N, Rodina M, Kocour M, Gela D, Flajshans M et al. (2006) Quantity, motility and fertility of tench Tincatinca (L.) sperm in relation to LHRH analogue and carp pituitary treatments. Aquacult Int 14: 75-87.

35. Wyrobek AJ, Gordon LA, Burkhart JG, Francis MW, Kapp RW et al. (1983) An evaluation of the mouse sperm morphology test and other sperm tests in nonhuman mammals. A report of the U.S. Environmental Protection Agency GeneTox Program. Mutat Res 115: 1-72.

36. Eliasson R, Treichl L (1971) Supravital staining of human spermatozoa. Fertility and Sterility 22: 134-137.

37. Rinchard J, Kestemont P (1996) Comparative study of reproductive biology in single and multiple spawner cyprinid fish. I. Morphological and histological features. J Fish Biol 49: 883-894.

38. Copeland PA, Sumpter JP, Walker JP, Croft M (1986) Vitellogenin levels in male and female rainbow trout (Salmogairdneri richardson) at various stages of the reproductive cycle. Comp Biochem Physiol B 83: 487-493.

39. Thorpe KL, Hutchinson TH, Hetheridge MJ, Scholze M, Sumpter JP et al. (2001) Assessing the biological potency of binary mixtures of environmental estrogens using vitellogenin induction in juvenile rainbow trout (Oncorhynchus mykiss). Environ Sci Technol 35: 2476-2481.

40. Van den Belt K, Verheyen R, Witters H (2003) Comparison of vitellogenin responses in zebrafish and rainbow trout following exposure 
Citation: Asifa KP and Chitra KC (2019) Effect of Chlordecone on the Reproductive Potential of the Cichlid fish, Pseudetroplus maculatus (Bloch, 1795). J Aquat Res Mar Sci 2019: 163-177.

to environmental estrogens. Ecotoxicol Environ Saf 56: 271-281.

41. Donohoe RM, Curtis LR (1996) Estrogenic activity of chlordecone, $\mathrm{o}, \mathrm{p}^{\prime}$-DDT and o, p'-DDE in juvenile rainbow trout: induction of vitellogenesis and interaction with hepatic estrogen binding sites. Aquatic Toxicol 36: 31-52.

42. Adams SM, Brown AM, Goede RW (1993) A quantitative health assessment index for rapid evaluation of fish condition in the field. Transactions of the American Fisheries Society 122: 63-73.

43. Singh S, Srivastava AK (2015) Variations in hepatosomatic index (HSI) and gonadosomatic index (GSI) in fish Heteropneustes fossilis exposed to higher sub-lethal concentration to arsenic and copper. J Ecophysiol Occupational Health 15: 89-93.

44. Kinnberg KA, Korsgaard B, Bjerregaard PO, Jespersen AS (2000) Effects of nonylphenol and 17beta-estradiol on vitellogenin synthesis and testis morphology in male platyfish, Xiphophorus maculatus. J Exp Biol 203: 171-181.

45. Ali T, Abdel Aziz SH, El-Sayed AF, Zeid S (2017) Effects of nonylphenol on plasma steroids, vitellogenin synthesis and sex reversal in Nile tilapia (Oreochromis niloticus) fingerlings. Indian $\mathrm{J}$ Marine Sci 46: 521-528.

46. Linares Casenave J, Kroll KJ, Van Eenennaam JP, Doroshov SI (2003) Effect of ovarian stage on plasma vitellogenin and calcium in cultured white sturgeon. Aquaculture 221: 645-656.

47. Silversand C (1996) Vitellogenesis in teleost fish, a study of vitellogenin and egg lipids. Doctoral Thesis, University of Gothenburg, Department of ZooPhysiology, Goteborg.

48. Nagler JJ, Ruby SM, Idler DR, So YP (1987) Serum phosphoprotein phosphorus and calcium levels as reproductive indicators of vitellogenin in highly vitellogenic mature female and estradiol-injected immature rainbow trout (Salmo gairdneri). Canadian J Zoology 65: 2421-2425.

49. Cheek AO, Brouwer TH, Carroll S, Manning S, McLachlan JA et al. (2001) Experimental evaluation of vitellogenin as a predictive biomarker for reproductive disruption. Environ Health Perspect 109: 681-690.

50. Reis Henriques MA, Cruz MM, Pereira JO (1997) The modulating effect of vitellogenin on the synthesis of 17-beta-estradiol by rainbow trout (Oncorhynchus mykiss) ovary. Fish Physiol Biochem 16 181-186.

51. Yang H, Tiersch TR (2009) Sperm motility initiation and duration in a euryhaline fish, medaka (Oryzias latipes). Theriogenol 72: 386-392.

52. Morita M, Takemura A, Okuno M (2003) Requirement of $\mathrm{Ca}^{2+}$ on activation of sperm motility in euryhaline tilapia Oreochromis mossambicus. J Exp Biol 206: 913-921.

53. Morisawa M, Suzuki K (1980) Osmolality and potassium ion: their roles in initiation of sperm motility in teleosts. Science 210: 11451147.

54. Le MH, Lim HK, Min BH, Park MS, Son MH et al. (2011) Effects of varying dilutions, $\mathrm{pH}$, temperature and cations on spermatozoa motility in fish Larimichthys polyactis. J Environ Biol 32: 271-276.

55. Alavi SMH, Cosson J (2005) Sperm motility in fishes-I. Effects of temperature and $\mathrm{pH}$ : a review. Cell Biol Int 29: 101-110.

56. Heath AG. Water Pollution and Fish Physiology, $2^{\text {nd }}$ ed, revised, CRC press, 1995.

57. Neumann F. Effects of drugs and chemicals on spermatogenesis. In: Chambers PL, Preziosi P, Chambers CM (Eds) Disease, metabolism and reproduction in the toxic response to drugs and other chemicals. Archives in Toxicology Springer, Berlin, Heidelberg, 1984.

58. Asifa KP, Chitra KC (2016) Induction of testicular oxidative stress by nonylphenol in cichlid fish, Etroplus maculatus (Bloch, 1795). Int J Fisher and Aquatic Stud 4: 453-456.

59. Bayley M, Junge M, Baatrup E (2002) Exposure of juvenile guppies to three antiandrogens causes demasculinization and a reduced sperm count in adult males. Aquat Toxicol 56: 227-239.

60. Lahnsteiner F, Mansour N, Berger B (2004) The effect of inorganic and organic pollutants on sperm motility of some freshwater teleosts. J Fish Biol 65: 1283-1297.

61. Tualla IPB, Bitacura JG (2016) Effects of cadmium and zinc on the gamete viability, fertilization, and embryonic development of Tripneustes gratilla (Linnaeus). Scientifica 1-10.

62. Marquardt H, Schafer S, McClellan RO, Welsch F. Toxicology, 1st Edition, Academic press, 1999.

63. Linder RE, Scotti TM, McElroy WK, Laskey JW, Strader LF et al. (1983) Spermotoxicity and tissue accumulation of chlordecone (Kepone) in male rats. J Toxicol Environ Health 12: 183-192.

64. Kao SH, Chao HT, Chen HW, Hwang TI, Liao TL et al. (2008) Increase of oxidative stress in human sperm with lower motility. Fertil Steril 89: 1183-1190.

65. Asifa KP, Chitra KC (2018) Chlordecone-induced changes in the ovarian and testicular antioxidant system in the cichlid fish, Pseudetroplus maculatus (Bloch, 1795). Iranian Journal of Fisheries Sciences (Under review). 


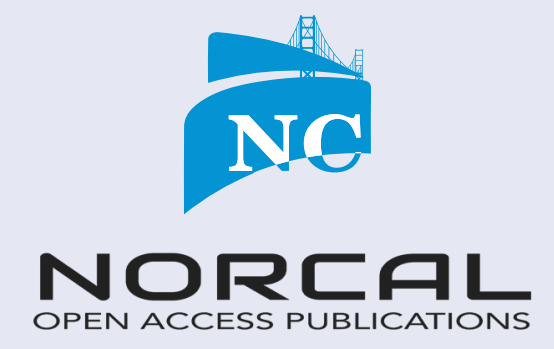

submit your manuscripts at www. norcaloa.com 